\title{
Fish versus starfish predation in controlling sea urchin populations in Mediterranean rocky shores
}

\author{
Chiara Bonaviri ${ }^{1, *}$, Tomás Vega Fernández ${ }^{2}$, Fabio Badalamenti ${ }^{2}$, Paola Gianguzza ${ }^{1}$, \\ Manfredi Di Lorenzo ${ }^{1}$, Silvano Riggio ${ }^{1}$
}

\author{
${ }^{1}$ Università di Palermo, Dipartimento di Ecologia, Via Archirafi 18, 90123 Palermo (PA), Italy \\ ${ }^{2}$ Consiglio Nazionale delle Ricerche - Instituto per l'Ambiente Marino Costiero (CNR-IAMC), Laboratorio di Ecologia Marina, \\ Via G. da Verrazzano 17, 91014 Castellammare del Golfo (TP), Italy
}

\begin{abstract}
In the Mediterranean, fishing bans generally allow the recovery of populations of sea urchin predators, such as the seabreams Diplodus sargus and D. vulgaris, promoting the transformation of overgrazed communities into ones dominated by erect macroalgae. However, in the marine reserve on Ustica Island (SW Italy) the opposite trend has occurred in the upper infralittoral community, and urchin barrens formed after the cessation of fishing activities. We hypothesized that (1) the natural scarcity of the 2 seabream species leads to a low predation rate on sea urchins at Ustica, and (2) predation rate varies with depth, due to differences in the predator assemblages. Tethering experiments were conducted to test these hypotheses by comparing the predation rates at different depths at Ustica and 2 other locations in Sicily characterized by erect macroalgae communities and low urchin densities. Differences in the assemblages of predators, relative vulnerability of the 2 species of sea urchin present (Paracentrotus lividus and Arbacia lixula), and sea urchin density were also assessed. Despite large variation in predator abundance among locations, there was no difference in predation rate on tethered urchins. Predation by fish was found to be higher in locations where seabreams were abundant, while predation by the starfish Marthasterias glacialis, usually considered a minor sea urchin predator, was found to be the major source of mortality at Ustica. The paucity of predatory fish at Ustica was consistent with the high abundances of urchins and persistence of barrens habitat. The high predation rate on urchins by $M$. glacialis at Ustica suggests that this species might play an important role in controlling urchin populations in the future.
\end{abstract}

KEY WORDS: Top-down control · Community dynamics · Sea urchin · Barrens · Seabream · Diplodus spp. $\cdot$ Marthasterias glacialis $\cdot$ Sicily

Resale or republication not permitted without written consent of the publisher

\section{INTRODUCTION}

Coastal ecosystems are often top-down regulated (Jackson et al. 2001). Over-exploitation of predators can cause outbreaks of prey populations (e.g. efficient grazers or superior competitors), promoting a dominance shift in benthic communities through trophic cascades (Durán \& Castilla 1989, McClanahan \& Muthiga 1998, Steneck 1998, Dulvy et al. 2004, Mumby et al. 2007). A typical example of such a process in shallow rocky habitats is the formation of areas overgrazed by sea urchins, usually referred to as urchin barrens (Mann 1982, Elner \& Vadas 1990, Estes
\& Duggins 1995, Sala et al. 1998, Tegner \& Dayton 2000, Jackson et al. 2001, Tuya et al. 2004). Given that erect macroalgae are habitat-forming species, deforestation caused by high sea urchin densities is likely to provoke a community-wide change towards an 'undesired' state characterized by encrusting communities with low structural complexity and few species present (McClanahan \& Sala 1997, Lilley \& Shiel 2006). Macroalgae depletion affects the densities of those predators of sea urchins which require the spatial complexity of macroalgal canopies as habitat (Steneck et al. 2004 and references therein). In addition, sea urchin grazing is facilitated in deforested areas (Konar 
\& Estes 2003). Overall, these mechanisms increase barren resilience through positive feedback (Scheffer \& Carpenter 2003, Petraitis \& Dudgeon 2004, Suding et al. 2004).

A pristine community may be re-established by a perturbation. Severe storms may decimate sea urchin populations and favour re-growth of kelp (Ebeling et al. 1985). In marine reserves (MRs) the ban of extractive human activities usually leads to recovery of key predators controlling sea urchin populations and restoring macroalgal-dominated habitats (Pinnegar et al. 2000, Shears \& Babcock 2002, 2003, Guidetti 2006, Pederson \& Johnson 2006, Guidetti \& Sala 2007, Sonnenholzner et al. 2009).

In the Mediterranean rocky sublittoral, the most abundant sea urchin species are Paracentrotus lividus and Arbacia lixula. Several predators, such as fish, lobster, starfish and gastropods, are able to prey on these species (Savy 1987, Guidetti 2004). However, only Diplodus sargus and Diplodus vulgaris (hereafter 'seabreams') have been reported to effectively control sea urchin populations (Sala \& Zabala 1996, Guidetti 2004, Guidetti 2006). Accordingly, depletion of these vertebrate predators by fishing can result in increased populations of the 2 sea urchin species, consequently triggering the formation of barren areas (Sala et al. 1998, Guidetti 2006, Hereu 2006). The 2 seabream species display a similar predatory role (Sala 1997, Guidetti 2006) forming a functional trophic group that positively responds to protection (Guidetti \& Sala 2007). The population densities of these seabreams typically augment in MRs and, beyond a critical threshold, activate a trophic cascade where urchin numbers are reduced and erect algal assemblages eventually increase (Guidetti \& Sala 2007). However, a different situation can also occur. Some remote Mediterranean islands are characterized by a naturally low density of Diplodus spp., most likely due to the lack of suitable habitats for recruitment (HarmelinVivien et al. 1995). This is the case at Ustica Island (La Mesa \& Vacchi 1999), where densities of the edible $P$. lividus and the co-occuring $A$. lixula increased enormously after enforcement of protection in 1991. It is likely that the natural scarcity of fish predators and the ban of human harvesting favoured this process (Gianguzza et al. 2006). As a consequence, a barren status spread extensively from the shallow ( 2 to $5 \mathrm{~m}$ ) to moderately deep ( 7 to $10 \mathrm{~m}$ ) rocky sublittoral (Riggio \& Milazzo 2004). The density of A. lixula is particularly high in the shallow waters of Ustica where, due to its morphological traits (i.e. a great adhesiveness to smooth substrate, Guidetti \& Mori 2005) it is less vulnerable to fish attacks. By contrast, $P$. lividus, which shows a cryptic behaviour (Sala \& Zabala 1996, Hereu 2006) and a relatively poor ability to adhere to rocks, is more prone to fish predation (Guidetti 2004, Guidetti \& Mori 2005). At Ustica, sea urchin density remains low at over $8 \mathrm{~m}$ depth, where communities are dominated by erect macroalgae (authors' pers. obs.). After the sea urchin outbreak at Ustica, populations of the starfish Marthasterias glacialis unexpectedly increased (pers. obs.). While sea urchins have been found in the diet of M. glacialis (Savy 1987), in the Mediterranean rocky sublittoral they are not considered to be preferred prey (Guidetti 2004) and there is little evidence that M. glacialis can control sea urchin populations (Dance \& Savy 1987, Fanelli et al. 1998).

The aims of the present study were to compare (1) the densities of Paracentrotus lividus and Arbacia lixula, (2) the abundance of sea urchin predators (seabream and Marthasterias glacialis), and (3) the predation rate on sea urchins at locations characterized by either the presence or the absence of a barren habitat. We predicted that, compared to vegetated areas, density of sea urchins in barren habitats would be higher but abundance of seabreams and predation rate lower. We selected study areas where sea urchin harvesting is prohibited, because it causes depletion of $P$. lividus populations. We also tested the effect of depth on the response variables mentioned above because barrens are usually found at moderate depth. Depth itself is not responsible for the paucity of sea urchins but it is probably correlated with fish predation pressure (Boudouresque \& Verlaque 2001); the size of seabreams increases with depth (Bell 1983, HarmelinVivien et al. 1995) and larger fish are more effective in eating adult sea urchins (Sala 1997, Guidetti 2004).

\section{MATERIALS AND METHODS}

Study area. The present study was carried out in the no-take areas of 3 Sicilian marine reserves (MRs) in southwestern Italy: Ustica MR (UMR), Capo GalloIsola delle Femmine MR (GFMR), and Lo Zingaro natural reserve (ZIR). UMR was established in 1986, but protection was effective only after enforcement started in 1991. It is located on a small volcanic island off the Sicilian coastline, covering 16000 ha, and the no-take zone extends for 65 ha along the NW part of the island. GFMR was established in 2002 on the NW coast of the Sicilian mainland and occupies 320854 ha; the no-take zone extends for $77 \mathrm{ha}$, distributed between the mainland and the the small rocky island of 'Isola delle Femmine' lying $500 \mathrm{~m}$ from the mainland; the area considered in this study is located off the NW part of this island. ZIR was established in 1981, on the western coast of the Gulf of Castellammare (NW coast of Sicily). The area is characterized by steep dolomitic cliffs. Its status differs from that of the other 
2 locations as it is entirely a terrestrial no-take zone, covering $7 \mathrm{~km}$ of coastline Although the extent of the protected seashore is limited, it results in effective protection of the rocky sublittoral communities of the area because the bottom generally drops well below $50 \mathrm{~m}$ outside the reserve boundaries, concentrating the rocky fauna in ZIR within a narrow band adjacent to the shoreline. All locations benefit from a similar surveillance effort, are open to dominant northern winds and are similarly exposed to other environmental variables. The algal communities were dominated by Cystoseira spp. stands in all locations, but UMR infralittoral turned to barrens after protection and enforcement (Riggio \& Milazzo 2004).

Experimental design. The abundance of seabreams and starfish was assessed in the 3 MRs. For each location, 2 similar sites were selected (Fig. 1). We considered 2 depths spanning the bathymetric range in which the local barren grounds appear. The experimental design therefore considered 3 factors: Location (L), fixed with 3 levels (UMR, GFMR and ZIR); Site (Si), random and nested in L (Site 1 and Site 2, separated by 200 to $400 \mathrm{~m}$ ); Depth (D), fixed with 2 levels (Shallow: 3 to $7 \mathrm{~m}$ and Deep: 13 to $17 \mathrm{~m}$ ). There were 8 replicates per experimental cell.

Densities of sea urchins were sampled in each location following an experimental design similar to that described above, but here a 4 th, orthogonal and fixed factor was added: Species (Sp) with 2 levels (Paracentrotus lividus and Arbacia lixula). Moreover, the factor $\mathrm{Si}$ was nested in the interaction term $\mathrm{L} \times \mathrm{D}$ due to the high spatial variability of sea urchin populations at the scale of a few meters. Ten replicates were sampled per cell, counting independently each species of sea urchin.

Predation rates on Paracentrotus lividus and Arbacia lixula were estimated with a tethering experiment. Trials were carried out following an experimental design analogous to the 4factor sea urchin abundance experiments above. Since predation was expected to be carried out by fishes, the term Site was nested in Location in this experimental design. There were 10 replicates per cell in this tethering experiment.

Sampling procedures. Densities of the seabream were estimated by visual census along strip transects (transect length $\times$ width $\times$ depth $50 \times 5 \times 5 \mathrm{~m})$ following Harmelin-Vivien \& Harmelin (1975). Individual fish total length (TL) was also visually estimated to the nearest $\mathrm{cm}$. The abundance of Marthasterias glacialis was quantified by visual census along nar- rower strip transects (length $\times$ width $50 \times 2 \mathrm{~m}$ ), with special attention to rocky crevices. If the detected starfish was feeding, the preyed species was identified. Sampling was performed during mornings from August to September 2006, for a total of 96 counts for both fish and starfish.

Densities of both Paracentrotus lividus and Arbacia lixula individuals ( $>1 \mathrm{~cm}$ test diameter) were estimated by independent visual counts within $1 \mathrm{~m}^{2}$ quadrats in February 2008, for a total of 240 counts.

Predation rates on sea urchins were measured through tethering experiments. Individuals of intermediate size ( 3 to $3.5 \mathrm{~cm}$ test diameter) were selected since predation affects mostly this size range in natural conditions (Sala \& Zabala 1996, Guidetti 2006). Tethering has been effectively applied to estimate predation rates on sea urchins in coral and rocky reefs habitats (McClanahan \& Muthiga 1989, Sala \& Zabala 1996,

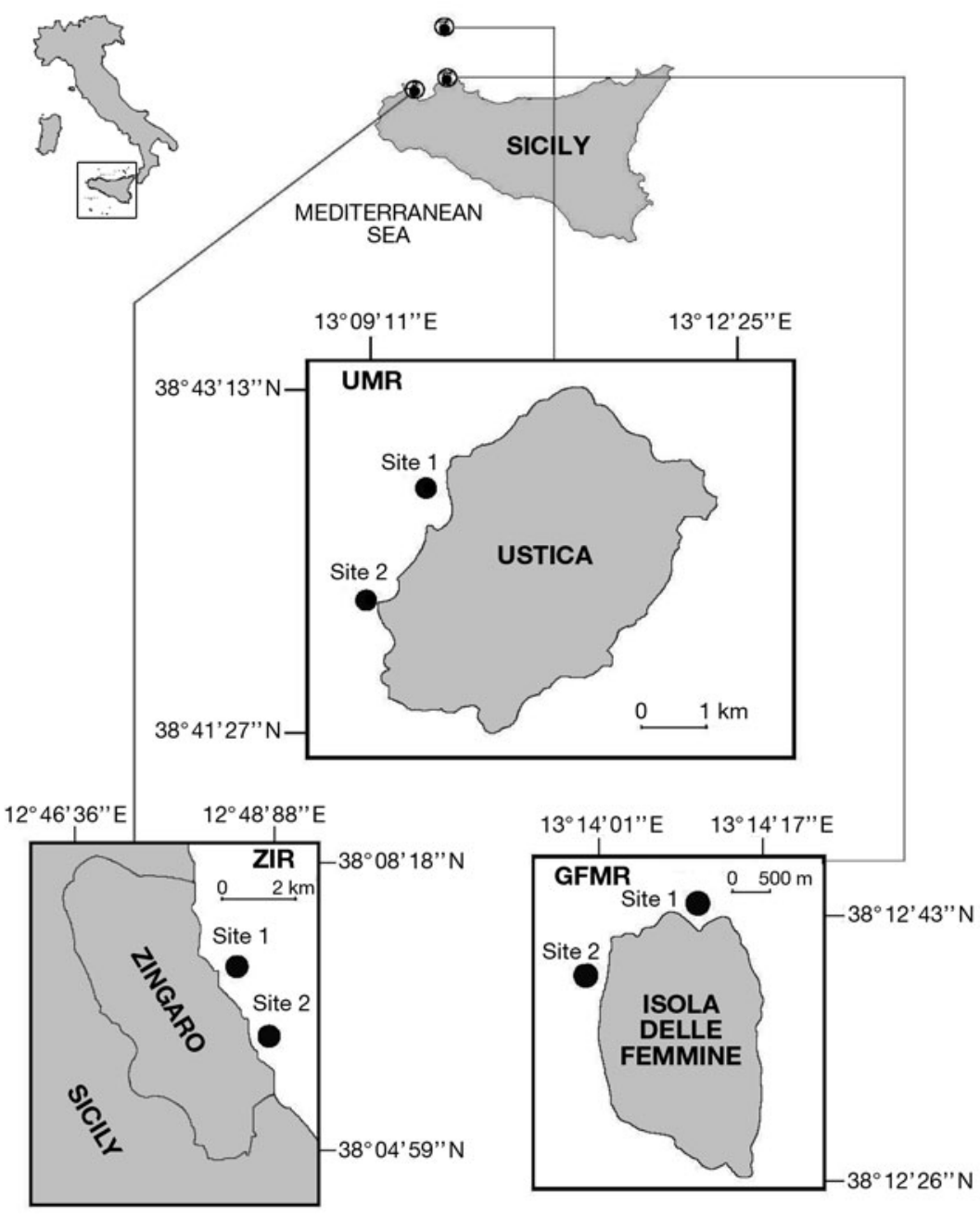

Fig. 1. Study sites in 3 Sicilian marine reserves (MR): Ustica MR (UMR), Capo Gallo-Isola delle Femmine MR (GFMR), and Lo Zingaro natural reserve (ZIR) 
Shears \& Babcock 2002). Sea urchins were tethered with a fishing line $(0.3 \mathrm{~mm}$ diameter; $30 \mathrm{~cm}$ length) passing from the oral to the aboral section of the test (McClanahan \& Muthiga 1989). A group of 3 tethered individuals was then tied to an anchor weight of $1 \mathrm{~kg}$, forming one experimental unit (EU). EUs were placed on erect macroalgae beds in the shallow and deep strata, at least $10 \mathrm{~m}$ apart from each other. In barren areas, EUs were put on isolated patches of erect macroalgae. A total number of 240 EUs were sampled $72 \mathrm{~h}$ after deployment, and the predation rate calculated as the number of sea urchins eaten in each EU divided by 3 .

Mortality due to the tethering manipulation itself was estimated by caging trials excluding predators. Three replicates for each combination of experimental factors were considered in these trials. Tethering-induced mortality was low $(9 \%)$ and uniformly distributed among experimental blocks. None of the tethered sea urchins were found detached from the anchor within the cages.

Sea urchin mortality was attributed to 3 sources (Savy 1987, authors' pers. obs.): (1) predation by fish (characterized by missing tests with intact nylon loop or broken tests with firmly attached spines), (2) predation by starfish (intact bare tests next to piles of freshly detached spines and dissembled Aristotle's lanterns), and (3) mortality due to manipulationinduced stress (intact test with loosely attached spines and some lacking in the oral zone).

Data analysis. The untransformed predation rates, the log-transformed biomass of seabreams (Diplodus sargus plus $D$. vulgaris) and the 4 th root transformed densities of sea urchins met the assumption of homogeneity of variances in Cochran's $C$-tests, but the abundance of M. glacialis did not, even after transformations were applied. Thus, ANOVAs were computed on the first 3 variables but not on the starfish abundances. Subsequent pairwise comparisons were performed by Student-Newman-Keuls (SNK) tests (Underwood 1997).

\section{RESULTS}

\section{Abundance of urchin predators}

Seabream density was consistently lowest at UMR (Fig. 2). The effect of depth on seabream density was strongly dependent on location (Table 1). The SNK tests showed that seabreams were equally scarce in the 2 depths at UMR. By contrast, they were more abundant in the shallow stratum at GFMR, and the pattern was reversed at ZIR. In addition, seabream density was equal in the shallow strata of GFMR and ZIR, while in the deep stratum seabreams were more frequent in ZIR (Fig. 2).

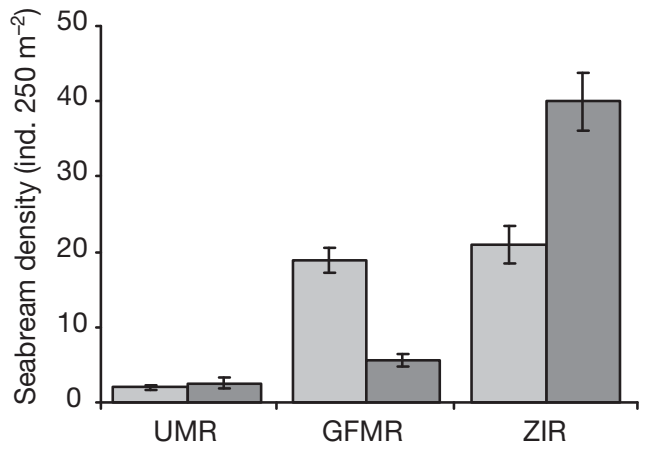

Fig. 2. Diplodus sargus and D. vulgaris. Combined density of the 2 seabream species in the 3 MRs at 2 depths: Shallow (light grey bars) and Deep (dark grey bars). Mean number of individuals per $250 \mathrm{~m}^{2} \pm 1$ SE. Abbreviations as in Fig. 1

Distribution of size-frequencies of seabreams (Fig. 3) showed that individuals $>29 \mathrm{~cm}$ TL were rare and exclusively found in the deep strata at UMR and GFMR. Medium-sized specimens were the most abundant class, except in the deep stratum of UMR (mainly composed of large individuals) and in the shallow stratum of ZIR (dominated by small individuals).

The starfish Marthasterias glacialis was considerably more abundant at UMR (29 ind. censused), particularly at shallow depths. About $25 \%$ of the M. glacialis recorded were found preying on sea urchins without any apparent preference for either of the 2 species considered here. Starfish were almost absent in the other locations; only 1 individual was found in the deep stratum at GFMR while feeding on a sea urchin (Fig. 4).

\section{Abundance of sea urchins}

Overall, sea urchins were most abundant in the shallow stratum at UMR. The SNK tests conducted on the levels of the $\mathrm{L} \times \mathrm{D}$ term indicate that sea urchin density (no. ind. $\mathrm{m}^{-2}$ ) in the shallow strata was highest at UMR and lowest at ZIR. By contrast, density was equal

Table 1. Diplodus sargus and D. vulgaris. ANOVA on the logtransformed abundance of the 2 seabream species among the 3 Locations (L), 2 Sites per Location $(\mathrm{Si}(\mathrm{L}))$ and 2 Depths (D).

$$
{ }^{* *} \mathrm{p}<0.01
$$

\begin{tabular}{|lcrrl|}
\hline Source of variation & df & MS & $F$ & \multicolumn{1}{c|}{ p } \\
\hline Location & 2 & 27.84 & 66.58 & 0.1546 \\
Site $(\mathrm{L})$ & 3 & 0.42 & 0.94 & $0.0029^{* *}$ \\
Depth & 1 & 0.47 & 2.56 & 0.5305 \\
$\mathrm{~L} \times \mathrm{D}$ & 2 & 5.70 & 31.38 & $0.0074^{* *}$ \\
$\mathrm{D} \times \mathrm{Si}(\mathrm{L})$ & 3 & 0.18 & 0.41 & 0.4118 \\
Residual & 84 & 0.45 & & \\
Total & 95 & & & \\
\hline
\end{tabular}


among the studied locations in the deep strata. The abundance of sea urchins decreased with depth at UMR and GFMR, but this pattern was not evident at ZIR (Fig. 5, Table 2).

\section{Predation rate}

There was no difference in total predation rates among the 3 locations. Predation rates varied with depth, but following a different trend at each location. The effect of depth on predation rates was also distinct between the 2 sea urchin species (Fig. 6, Table 3). At UMR, the highest level of predation on sea urchins was recorded in the shallow stratum, while at GFMR and ZIR predation rates were equal in shallow and deep strata. In the deep strata, predation rates were higher at GFMR than at UMR or ZIR, which both presented similar predation rates. Between depth strata, rates of predation on Paracentrotus lividus were higher than on Arbacia lixula in the deep strata. Comparison between species showed that predation on A. lixula was higher in the shallow strata than in the deep strata, while the pattern was reversed for P. lividus. Predation rates displayed prey-specific spatial variability, measurable on the scale of $100 \mathrm{~m}$, as indicated by the significant effect of the $\mathrm{Sp} \times$ $\mathrm{Si}(\mathrm{L})$ term (Table 2). Starfish were responsible for most of the sea urchin mortality at UMR. At this location, starfish predation on $P$. lividus accounted for more than half of the predation on sea urchins in the shallow stratum $(55 \%)$ and this proportion further increased in the deep stratum $(83 \%)$. This pattern was reversed in the case of $A$. lixula, for which starfish predation was $67 \%$ in the shallow stratum but only $50 \%$ in the deep stratum (Fig. 6).

In GFMR, starfish predation on Paracentrotus lividus was low $(27 \%)$ in the shallow stratum and zero in the deep stratum. By contrast, starfish predation accounted for higher proportions of killed individuals of Arbacia lixula in both the shallow (55\%) and deep (32\%) strata (Fig. 6).

In ZIR, starfish predation was generally very low. Starfish were responsible for $5 \%$ of the killed Paracentrotus lividus in the deep stratum and none in the shallow stratum. Regarding Arbacia lixula, proportions were $4 \%$ and $6 \%$, respectively (Fig. 6 ).

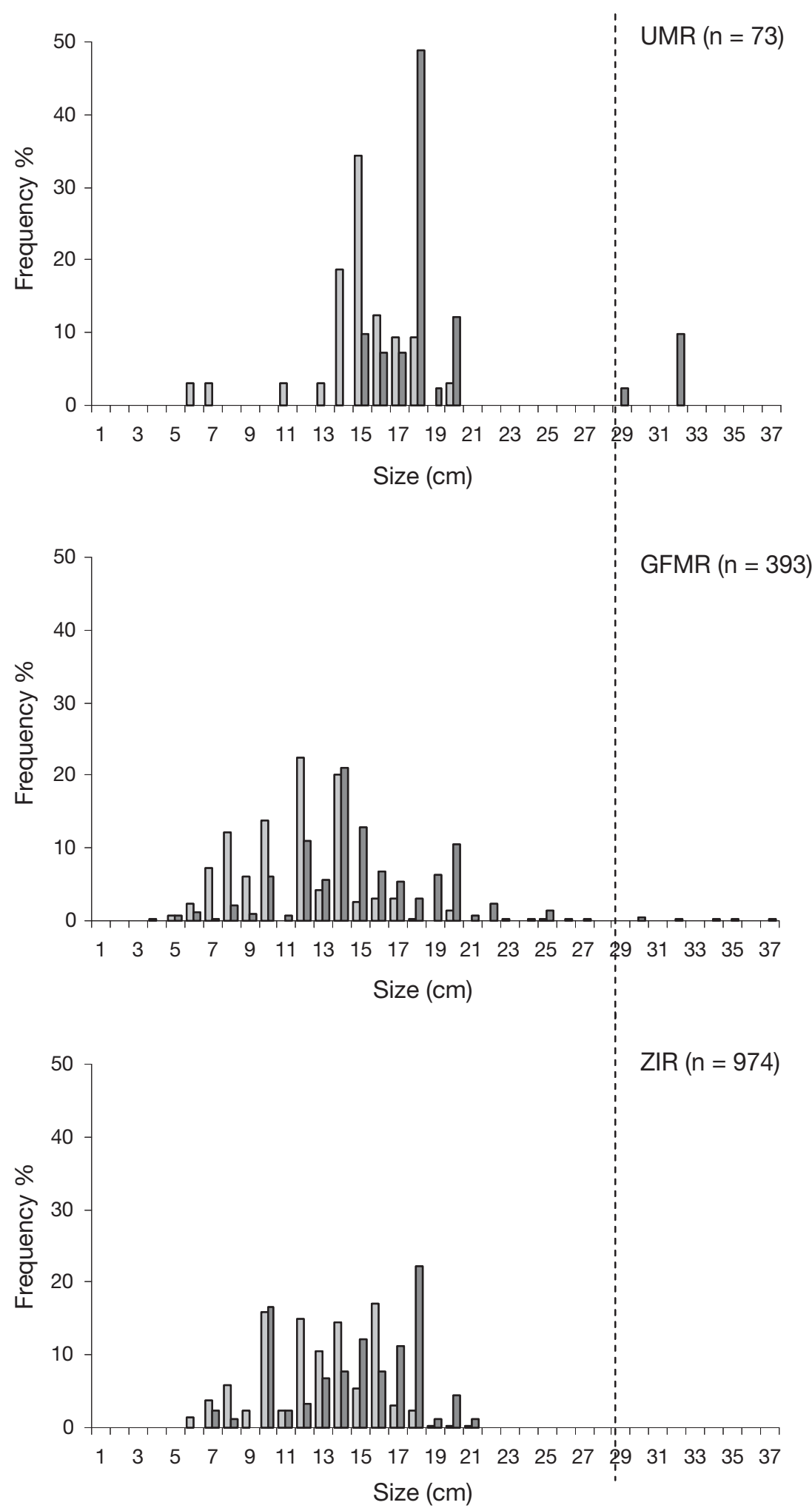

Fig. 3. Diplodus sargus and D. vulgaris. Combined size frequency distribution (\%) of the 2 seabream species in the 3 MRs at 2 depths: Shallow (light grey bars) and Deep (dark grey bars). The dashed line indicates the threshold size reported to be able to predate on the sea urchins used in this study. n: number of individuals, other abbreviations as in Fig. 1 


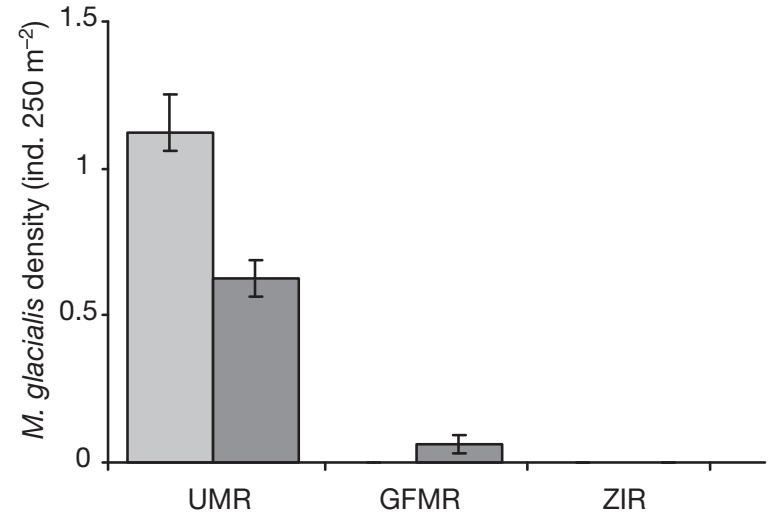

Fig. 4. Marthasterias glacialis. Density of seastars in the 3 MRs at 2 depths: Shallow (light grey bars) and Deep (dark grey bars). Mean number of individuals per $250 \mathrm{~m}^{2} \pm 1 \mathrm{SE}$. Abbreviations as in Fig. 1

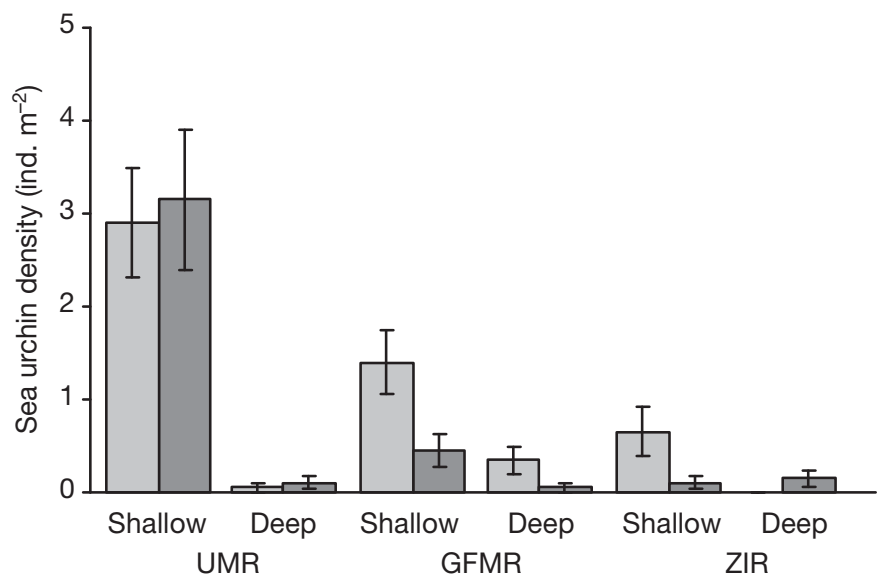

Fig. 5. Paracentrotus lividus (light grey bars) and Arbacia lixula (dark grey bars). Densities of the 2 sea urchin species in the 3 MRs at 2 depths (mean number of individuals per $\mathrm{m}^{2} \pm$ $1 \mathrm{SE})$. Abbreviations as in Fig. 1

Table 2. Paracentrotus lividus and Arbacia lixula. ANOVA on the 4th root transformed abundance of 2 sea urchin species among 3 Locations (L), 2 Depths (D), 2 Sites per Location and Depth $(\operatorname{Si}(\mathrm{L} \times \mathrm{D}))$, and 2 Species $(\mathrm{Sp}) .{ }^{* *} \mathrm{p}<0.01$

\begin{tabular}{|lcrrl|}
\hline Source of variation & df & MS & $F$ & $p$ \\
\hline Location & 2 & 5.02 & 41.40 & $0.0003^{* *}$ \\
Depth & 1 & 18.96 & 156.51 & $0.0000^{* *}$ \\
Si $(\mathrm{L} \times \mathrm{D})$ & 6 & 0.12 & 0.79 & 0.5750 \\
Species & 1 & 0.82 & 3.77 & 0.1002 \\
$\mathrm{~L} \times \mathrm{D}$ & 2 & 5.42 & 44.75 & $0.0002^{* *}$ \\
$\mathrm{~L} \times \mathrm{Sp}$ & 2 & 0.69 & 3.20 & 0.1135 \\
$\mathrm{D} \times \mathrm{Sp}$ & 1 & 0.73 & 3.37 & 0.1159 \\
$\mathrm{Sp} \times \mathrm{Si}(\mathrm{L} \times \mathrm{D})$ & 6 & 0.22 & 1.42 & 0.2080 \\
$\mathrm{~L} \times \mathrm{D} \times \mathrm{Sp}$ & 2 & 0.17 & 0.76 & 0.5066 \\
Residual & 216 & 0.15 & & \\
Total & 239 & & & \\
\hline
\end{tabular}

\section{DISCUSSION}

In the Mediterranean Sea, high densities of the sea urchins Paracentrotus lividus and Arbacia lixula may produce and maintain coralline barrens (Sala et al. 1998, Bulleri et al. 1999), leading to drastic changes in ecosystem functioning (Sala et al. 1998). A high abundance of Diplodus spp. usually leads to increased predation rate on sea urchins, reduction of sea urchin biomass (Sala \& Zabala 1996, Guidetti 2006, Guidetti \& Sala 2007) and finally to restoration of erect macroalgae cover (Guidetti 2006).

As expected, at all 3 locations a correlation between high density of sea urchins and barren habitat was found. Predator assemblages varied among the 3 locations and the 2 depths. Interestingly, the source of predation varied according to changes in predator assemblages. However, high predation rate on sea urchins did not always correspond to low sea urchin abundance. Moreover, fish predation rate did not correlate to visually estimated densities of seabreams.

At Ustica Island, abundance of sea urchins increased dramatically after the start of enforcement in 1991. The subsequent ban on sea urchin harvesting most probably favoured the increase of the edible Paracentrotus

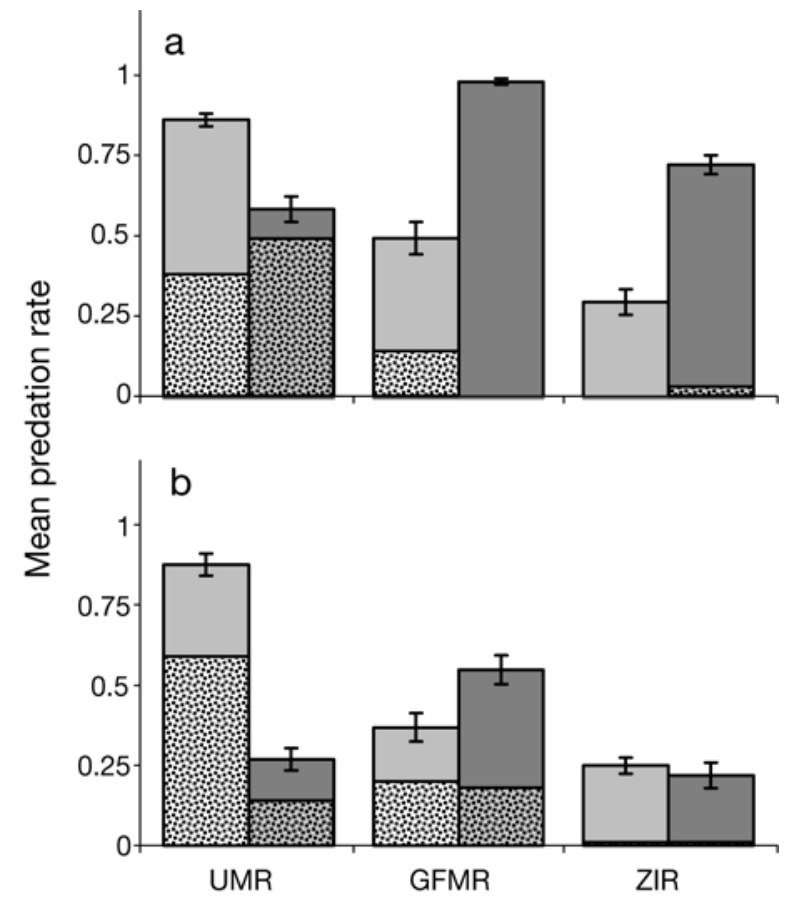

Fig. 6. (a) Paracentrotus lividus and (b) Arbacia lixula. Predation rates on the 2 sea urchin species in the 3 MRs after $72 \mathrm{~h}$ at 2 depths: Shallow (light grey bars) and Deep (dark grey bars). Mean number of predated individuals \pm 1 SE. Stippled part of bars indicates predation by starfish Marthasterias glacialis, non-stippled predation by seabream Diplodus spp. Abbreviations as in Fig. 1 
Table 3. Paracentrotus lividus and Arbacia lixula. ANOVA on the rates of predation on tethered adult sea urchins after $72 \mathrm{~h}$ among the 3 Locations (L), 2 Sites per Location $(\operatorname{Si}(\mathrm{L}))$, 2 Depths (D) and 2 Species (Sp). ${ }^{*} \mathrm{p}<0.05,{ }^{* *} \mathrm{p}<0.01$

\begin{tabular}{|lclcl|}
\hline Source of variation & df & MS & $F$ & \multicolumn{1}{c|}{$p$} \\
\hline Location & 2 & 1.7167 & 3.71 & 0.1546 \\
Site $(\mathrm{L})$ & 3 & 0.463 & 4.81 & $0.0029^{* *}$ \\
Depth & 1 & 0.0463 & 0.5 & 0.5305 \\
Species & 1 & 3.4241 & 12.84 & $0.0372^{*}$ \\
$\mathrm{~L} \times \mathrm{D}$ & 2 & 3.513 & 37.94 & $0.0074^{* *}$ \\
$\mathrm{~L} \times \mathrm{Sp}$ & 2 & 0.1185 & 0.44 & 0.6776 \\
$\mathrm{D} \times \mathrm{Si}(\mathrm{L})$ & 3 & 0.0926 & 0.96 & 0.4118 \\
$\mathrm{Sp} \times \mathrm{Si}(\mathrm{L})$ & 3 & 0.2667 & 2.77 & $0.0426^{*}$ \\
$\mathrm{Sp} \times \mathrm{D}$ & 1 & 2.0167 & 108.9 & $0.0019^{* *}$ \\
$\mathrm{SpxL} \times \mathrm{D}$ & 2 & 0.0389 & 2.1 & 0.269 \\
$\mathrm{Sp} \times \mathrm{D} \times \operatorname{Si}(\mathrm{Lo})$ & 3 & 0.0185 & 0.19 & 0.9016 \\
Residual & 216 & 0.0963 & & \\
Total & 239 & & & \\
\hline
\end{tabular}

lividus, but this species was soon overwhelmed by Arbacia lixula (Fig. 7). Previous studies hypothesized a 'bulldozing' effect of $P$. lividus on erect macroalgae, clearing foraging grounds for A. lixula (Maggiore et al. 1987). At this stage, re-colonization of barren grounds by erect macroalgae could have been prevented through intense grazing by the dense populations of A. lixula found in this habitat (Guidetti \& Dulčić 2007). The scarcity of seabreams at Ustica (La Mesa \& Vacchi 1999, this study) may have favoured the maintenance of high sea urchin densities. La Mesa \& Vacchi (1999) reported that the abundance of seabreams is lower within the no-take area of UMR than outside it, suggesting that the local seabream population is not limited by fishing pressure.

However, despite the paucity of Diplodus spp., predation rates in the shallow strata were higher at UMR than GFMR and ZIR, where seabreams are significantly more abundant. This unexpected result may be explained by the high densities of Marthasterias glacialis found at UMR.

In contrast to other studies (Sala \& Zabala 1996, Guidetti 2004, 2006, Guidetti \& Dulčić 2007) as well as observations at GFMR and ZIR, most of the tethered sea urchins at UMR were eaten by starfish ( $57 \%$ in the shallow stratum and $76 \%$ in the deep stratum). However, it must be noted that the measured predation pressure by Marthasterias glacialis is probably an overestimate of the real situation occurring at UMR because (1) the intrinsic features of the tethering strategy may have precluded the escape of sea urchins in response to the attack of the slow-moving starfish (Shears \& Babcock 2002), and (2) starfish are chemosensory predators (Valentinãiã 1985) and could have been preferably attracted to tethered urchins by chemical compounds released from wounds unintentionally caused by manipulation. Nevertheless, starfish may be an important agent in controlling sea urchin densities at Ustica Island. The lack of both natural predators (e.g. whelks, McClanahan 1989) and human exploitation (Dulvy et al. 2004) allow these voracious echinoderms to play the role of a key predator. In many intertidal systems, the presence of starfish limits competitive-dominant, space-monopolising mussels to the upper mid-zone and inter-tidal zone (Paine 1966, Menge \& Branch 2001). In subtidal zones, starfish outbreaks may cause cascading changes in the structure of coral communities (Dulvy et al. 2004) or influence the spatial distribution of sea urchins (Duggins 1983). A similar situation might occur at Ustica Island. About $10 \mathrm{yr}$ after the harvesting ban, sea urchin populations reached a maximum. Since then they have undergone a continuous decline (Fig. 7).

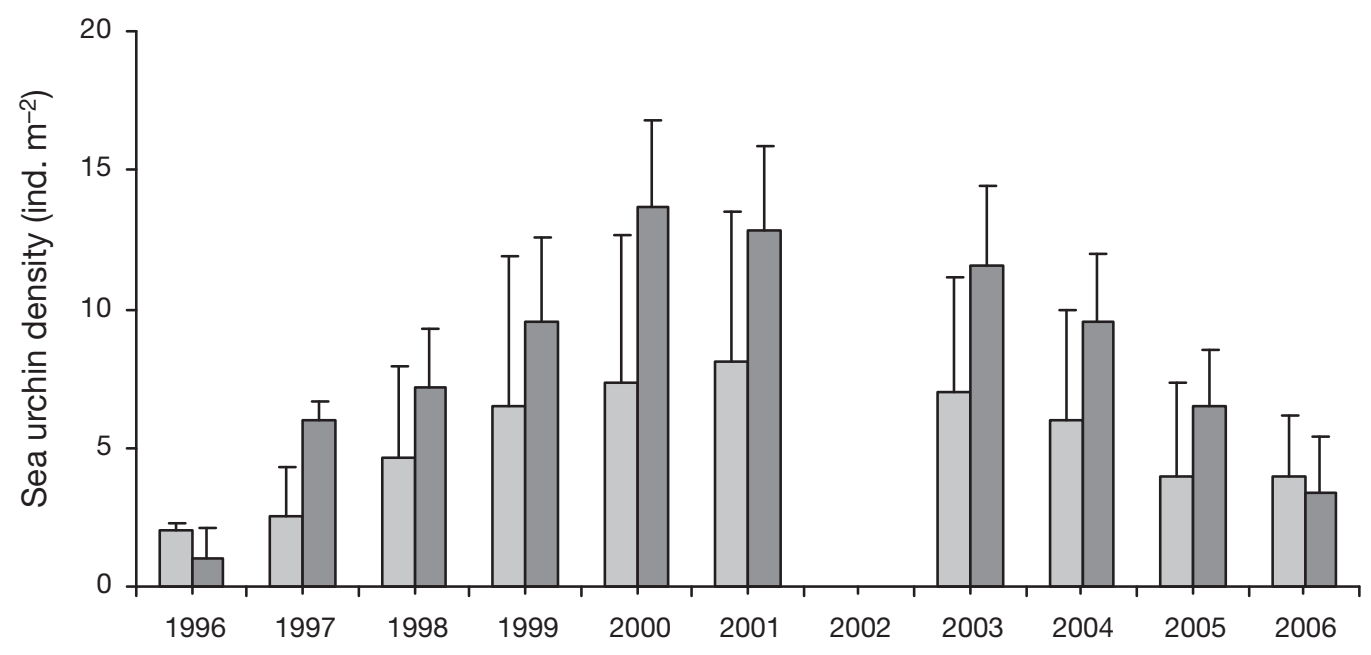

Fig. 7. Paracentrotus lividus (light grey bars) and Arbacia lixula (dark grey bars). Densities (mean number per $\mathrm{m}^{2} \pm \mathrm{SE}$ ) of the 2 sea urchin species recorded in the no take-zone of UMR from 1996 to 2006 (except for 2002) 
Unfortunately, there is no record of previous starfish density at Ustica, but starfish are reported to be more frequently spotted by local divers. Many M. glacialis have been observed feeding on sea urchins in recent years, and the remains of sea urchins clearly eaten by starfish are seen frequently at Ustica (Gianguzza et al. 2009). At other Mediterranean locations, a negative correlation between $M$. glacialis and sea urchin densities has been described (Fanelli et al. 1998). At the moment, the Ustica barren appears to be dominated by large echinoderms and this situation might lead to 2 different scenarios. Sea urchin and starfish populations could reach a stable equilibrium in which the community persists in the barren state as reported in temperate systems where predation of sea urchins by fish is particularly low (Shears \& Babcock 2002, Clemente et al. 2007). Alternatively, predation by invertebrate predators, such as starfish, might eventually control the populations of sea urchins, favouring the transition from a barren state to one dominated by erect macroalgae. The latter hypothesis is supported by the declining density of the 2 sea urchin species and by the current trend of decrease of the barren area at UMR in recent years (data from Ustica Port Authority internal reports). Similarly to the pattern observed at other Mediterranean locations where previously overexploited seabreams recovered, the deep strata of GFMR and ZIR are characterized by low sea urchin densities, high predation rate by fish and dominance of erect macroalgae. The link between the abundance of Diplodus spp. and the status of the benthic community in Mediterranean shallow ecosystems has been recently formulated in a quantitative way by Guidetti \& Sala (2007). These authors indicate a critical threshold in the density of seabream predators able to activate the transition from barrens to a community characterized by erect algae. While results obtained from the deep stratum of ZIR support this hypothesis, those from GFMR do not. A possible explanation might be predation by large fishes. Unfortunately, we have no direct observation of such a predation because such large fish are particularly wary of divers in areas subjected to intensive spear-gun fishing (Kulbicki 1998), as GFMR was until recent times. Nevertheless, this hypothesis is supported by (1) the frequent capture around GFMR of large individuals of Sparus aurata (B. Zava pers. comm.), which are able to feed on very large sea urchins (Sala 1997); (2) the finding of intact tether loops with no remains in the deep strata of GFMR and ZIR; and (3) the observation of very large seabreams below $25 \mathrm{~m}$ depth.

In contrast to the situation observed in the deep strata, predation rates in the shallow strata by fish were low at all 3 locations. The lack of Diplodus spp. $>20 \mathrm{~cm}$ in the shallow strata of the 3 locations may explain this pattern. Sea urchins with a test diameter of 3 to $3.5 \mathrm{~cm}$, like those utilized in the study, may only be broken and consumed by Diplodus $>29 \mathrm{~cm}$ (Sala 1997, Guidetti 2004). It is possible that the large fish predators which predated the tethered sea urchins in the deep strata of ZIR and GFMR limit their movement and activity to waters deeper than the shallow strata ( 3 to $7 \mathrm{~m}$ ). As the sea urchin densities in the shallow stratum are significantly higher at $\mathrm{UMR}$, it is unlikely that fish predation alone is able to control sea urchin populations in the shallow strata of GFMR and ZIR. Other mechanisms such as illegal harvesting, which has been observed, could be responsible for the low density of the edible sea urchin (and, as a trophic/habitat side effect, of Arbacia lixula) in the shallow strata of GFMR and ZIR.

We observed that fish preferred Paracentrotus lividus. However, in shallow strata, where the predation rate by fish was generally low, the prey preference was accordingly less clear. In order to reach palatable tissues, fish must detach sea urchins from the substrate or break down their test. Such requirements make $P$. lividus more vulnerable than Arbacia lixula because the former has shorter spines and is less firmly attached to the substrate (Guidetti 2004, Guidetti \& Mori 2005). On the other hand, M. glacialis shows no clear prey preference along all sites and locations, and differences are most likely due to indirect effects. For example, in the deep stratum of GFMR, earlier consumption of $P$. lividus by fish may prevent subsequent consumption of this species by the slow-moving starfish. By predating unspecifically, starfish might constitute a potentially more efficient controller of sea urchins in barren habitats where $A$. lixula is abundant.

In conclusion, our study confirms the importance of top-down control in regulating Mediterranean rocky systems, and suggests that asteroids or fish predators other than seabreams can also control sea urchin populations. Importantly, our results indicate that the threshold hypothesis on seabream densities (Guidetti \& Sala 2007) may not be as clear a cut-off as previously thought, since the low value found at an isolated island like Ustica corresponded to an intensity of fish predation similar to that of 2 mainland sites where seabreams are more abundant.

Acknowledgements. We are grateful to N. Shears and the 2 anonymous reviewers for their constructive and challenging comments, which substantially improved this manuscript, and to A. Barcellona, C. Scianna, D. Agnetta and D. Perricone for their help in the field. We are also grateful to the Harbour Office of Palermo, the MPA management body of the Ustica Island, for logistical support. This study was funded by the Ministero dell'Ambiente e Difesa del Territorio (MATT). 


\section{LITERATURE CITED}

Bell JD (1983) Effect of depth and marine reserved fishing restrictions on the structure of a rocky reef fish assemblage in the north-western Mediterranean sea. J Appl Ecol 20:357-369

Boudouresque CF, Verlaque M (2001) Ecology of Paracentrotus lividus. In: Lawrence JM (ed) Edible sea urchins: biology and ecology. Elsevier, Amsterdam, p 177-216

Bulleri F, Benedetti-Cecchi L, Cinelli F (1999) Grazing by the sea urchin Arbacia lixula L. and Paracentrotus lividus Lam. in the Northwest Mediterranean. J Exp Mar Biol Ecol 241:81-95

- Clemente S, Hernandez JC, Toledo K, Brito A (2007) Predation upon Diadema aff. antillarum in barren grounds in the Canary Islands. Sci Mar 71:745-754

Dance C, Savy S (1987) Predation on Paracentrotus lividus by Marthasterias glacialis: an in situ experiment at Port-Cros (France Mediterranean). Posidonia Newsl 1:35-41

$>$ Duggins DO (1983) Starfish predation and the creation of mosaic patterns in a kelp-dominated community. Ecology 64:1610-1619

> Dulvy NK, Freckleton RP, Polunin NVC (2004) Coral reef cascades and the indirect effects of predator removal by exploitation. Ecol Lett 7:410-416

Durán LR, Castilla JC (1989) Variation and persistence of the middle rocky intertidal community of central Chile, and without human harvesting. Mar Biol 103:555-562

Ebeling AW, Laur DR, Rowley RJ (1985) Severe storm disturbance and reversal of community structure in a southern California kelp forest. Mar Biol 84:287-294

> Elner RW, Vadas RL (1990) Inference in ecology: the sea urchin phenomenon in the Northwest Atlantic. Am Nat 136:108-125

Estes JA, Duggins DO (1995) Sea otters and kelp forest in Alaska: generality and variation in a community ecological paradigm. Ecol Monogr 65:75-100

Fanelli G, Piraino S, Esposito L, Geraci S, Boero F (1998) Opposite role of sea urchins and starfish in marine benthic communities. In: Candia Carnevali ND, Bonassoro F (eds) Echinoderm research. Balkema, Rotterdam, p 453-457

Gianguzza P, Badalamenti F, Gianguzza F, Bonaviri C, Riggio S (2009) The operational sex ratio of the sea urchin Paracentrotus lividus populations: the case of the Mediterranean marine protected area of Ustica Island (Tyrrhenian Sea Italy). PSZN I: Mar Ecol 30:125-132

Cianguzza P, Chiantore M, Bonaviri C, Cattaneo-Vietti R, Vielmini I, Riggio S (2006) The effects of recreational Paracentrotus lividus fishing on distribution patterns of sea urchins at Ustica Island MPA (Western Mediterranean, Italy). Fish Res 81:37-44

Guidetti P (2004) Consumers of sea urchins (Paracentrotus lividus and Arbacia lixula) in shallow Mediterranean rocky reefs. Helgol Mar Res 58:110-116

> Guidetti P (2006) Marine reserves reestablish lost predatory interactions and cause community changes in rocky reefs. Ecol Appl 16:963-976

Guidetti P, Dulčić J (2007) Relationship among predatory fish, sea urchins and barrens in Mediterranean rocky reefs across a latitudinal gradient. Mar Environ Res 63:168-184

Guidetti P, Mori M (2005) Morpho-functional defences of Mediterranean sea urchins, Paracentrotus lividus and Arbacia lixula, against fish predators. Mar Biol 147: 797-802

> Guidetti P, Sala E (2007) Community-wide effects of marine reserves in the Mediterranean Sea. Mar Ecol Prog Ser 335: 43-56

Harmelin-Vivien M, Harmelin JG (1975) Presentation of an 'in situ' evaluation method of the ichthyological fauna. Trav Sci Parc Natl Port Cros 1:47-52

Harmelin-Vivien M, Harmelin JG, Leboulleux V (1995) Microhabitat requirements for settlement of juvenile sparid fishes on Mediterranean rocky shores. Hydrobiologia 300-301:309-320

$>$ Hereu B (2006) Depletion of palatable algae by sea urchins and fish in a Mediterranean subtidal community. Mar Ecol Prog Ser 313:95-103

Jackson JBC, Kirby MX, Berger WH, Bjorndal KA and others (2001) Historical overfishing and the recent collapse of coastal ecosystems. Science 293:629-637

> Konar B, Estes JA (2003) The stability of boundary regions between kelp beds and deforested areas. Ecology 84: $174-185$

Kulbicki M (1998) How the acquired behaviour of commercial reef fish may influence the results obtained from visual censuses. J Exp Mar Biol Ecol 222:11-30

La Mesa G, Vacchi M (1999) An analysis of the coastal fish assemblages of the Ustica Island Marine Reserve (Mediterranean Sea). PSZN I: Mar Ecol 20:147-165

> Lilley SA, Shiel DR (2006) Community effect following the deletion of a habitat-forming alga from rocky marine shores. Oecologia 148:672-681

Maggiore F, Berthon JF, Boudouresque CF, Lawrence J (1987) Donnes préliminaires sur les relations entre Paracentrotus lividus, Arbacia lixula et le phytobenthos dans la baie de Port-Cros (Var, France, Méditerranée). In: Boudouresque CF (ed) Colloque International sur Paracentrotus lividus et les oursins comestibles. GIS Posidonie, Marseille, p 65-82

Mann KH (1982) Kelp, sea urchins and predators: a review of strong interactions in rocky subtidal system of Eastern Canada, 1970-1980. Neth J Sea Res 16:414-423

McClanahan TR (1989) Kenyan coral reef-associated gastropod fauna: a comparison between protected and unprotected reefs. Mar Ecol Prog Ser 53:11-20

McClanahan TR, Muthiga NA (1989) Patterns of predation on a sea urchin, Echinometra mathaei, on Kenyan coral reef. J Exp Mar Biol Ecol 126:77-94

> McClanahan TR, Sala E (1997) A Mediterranean rocky-bottom ecosystem fisheries model. Ecol Model 104:145-164

Menge BA, Branch GM (2001) Rocky intertidal communities. In Bertness MD, Gaines SD, Hay NE (eds) Marine community ecology. Sinauer, Sunderland, MA, p 221-251

> Mumby PJ, Harborne AR, Williams J, Kappel CV and others (2007) Trophic cascade facilitates coral recruitment in a marine reserve. Proc Natl Acad Sci USA 104:8362-8367

Paine RT (1966) Food web complexity and species diversity. Am Nat 100:65-75

Pederson HG, Johnson CR (2006) Predation of the sea urchin Heliocidaris erythrogramma by rock lobster (Jasus edwardsii) in no-take marine reserves. J Exp Mar Biol Ecol 336:120-134

Petraitis PS, Dudgeon SR (2004) Detection of alternative stable states in marine communities. J Exp Mar Biol Ecol 300:343-371

Pinnegar JK, Polunin NVC, Francour P, Badalamenti F and others (2000) Trophic cascades in benthic marine ecosystems: lessons for fisheries and protected-area management. Environ Conserv 27:179-200

Riggio S, Milazzo M (2004) Ricchezza specifica e biodiversità marina nell'isola di Ustica. Nat Sicil 1:559-586

Sala E (1997) Fish predators and scavengers of the sea urchin Paracentrotus lividus in protected areas of the north-west Mediterranean Sea. Mar Biol 129:531-539

Sala E, Zabala M (1996) Fish predation and the structure of 
the sea urchin Paracentrotus lividus populations in the NW Mediterranean. Mar Ecol Prog Ser 140:71-81

Sala E, Boudouresque CF, Harmelin-Vivien M (1998) Fishing, trophic cascades, and the structure of algal assemblages: evaluation of an old but untested paradigm. Oikos 82: $425-439$

Savy S (1987) Les predateurs de Paracentrotus lividus (Echinodermata). In: Boudouresque CF (ed) Colloque International sur Paracentrotus lividus et les oursins comestibles. GIS Posidonie, Marseille, p 413-423

Shears NT, Babcock RC (2002) Marine reserves demonstrate top-down control of community structure on temperate reef. Oecologia 132:131-142

Shears NT, Babcock RC (2003) Continuing trophic cascade effects after 25 years of no-take marine reserve protection. Mar Ecol Prog Ser 246:1-16

Scheffer M, Carpenter SR (2003) Catastrophic regime shifts in ecosystems: linking theory to observation. Trends Ecol Evol 18:648-656

Sonnenholzner JI, Ladah BL, Lafferty KD (2009) Cascading effects of fishing on Galapagos rocky reef communities. Mar Ecol Prog Ser 375:209-218

Editorial responsibility: Laura Airoldi, Ravenna, Italy
Steneck RS (1998) Human influence on coastal ecosystems: does overfishing create trophic cascade? Trends Ecol Evol 13:429-430

Steneck RS, Vavrinec J, Leland AV (2004) Accelerating trophic-level dysfunction in kelp forest ecosystems of the Western North Atlantic. Ecosystems 7:323-332

Suding KN, Gross KL, Houseman GR (2004) Alternative states and positive feedbacks in restoration ecology. Trends Ecol Evol 19:46-53

Tegner MJ, Dayton PK (2000) Ecosystem effect of fishing in kelp forest communities. ICES J Mar Sci 57:579-589

- Tuya F, Boyra A, Sanchez-Jerez P, Barbera C, Haroun RJ (2004) Relationships between rocky-reef fish assemblages, the sea urchin Diadema antillarum and macroalgae throughout the Canarian Archipelago. Mar Ecol Prog Ser 278:157-169

Underwood AJ (1997) Experiments in ecology. Their logical design and interpretation using analysis of variance. Cambridge University Press, Cambridge

Valentinãiã T (1985) Behavioural study of chemoreception in the sea star Marthasterias glacialis: structure-activity relationships of lactic acid, amino acids, and acetylcholine. J Comp Physiol A 157:537-545

Submitted: June 30, 2008; Accepted: February 16, 2009

Proofs received from author(s): April 17, 2009 